Electronic scientific and practical journal INTELLECTUALIZATION OF LOGISTICS AND SUPPLY CHAIN MANAGEMENT

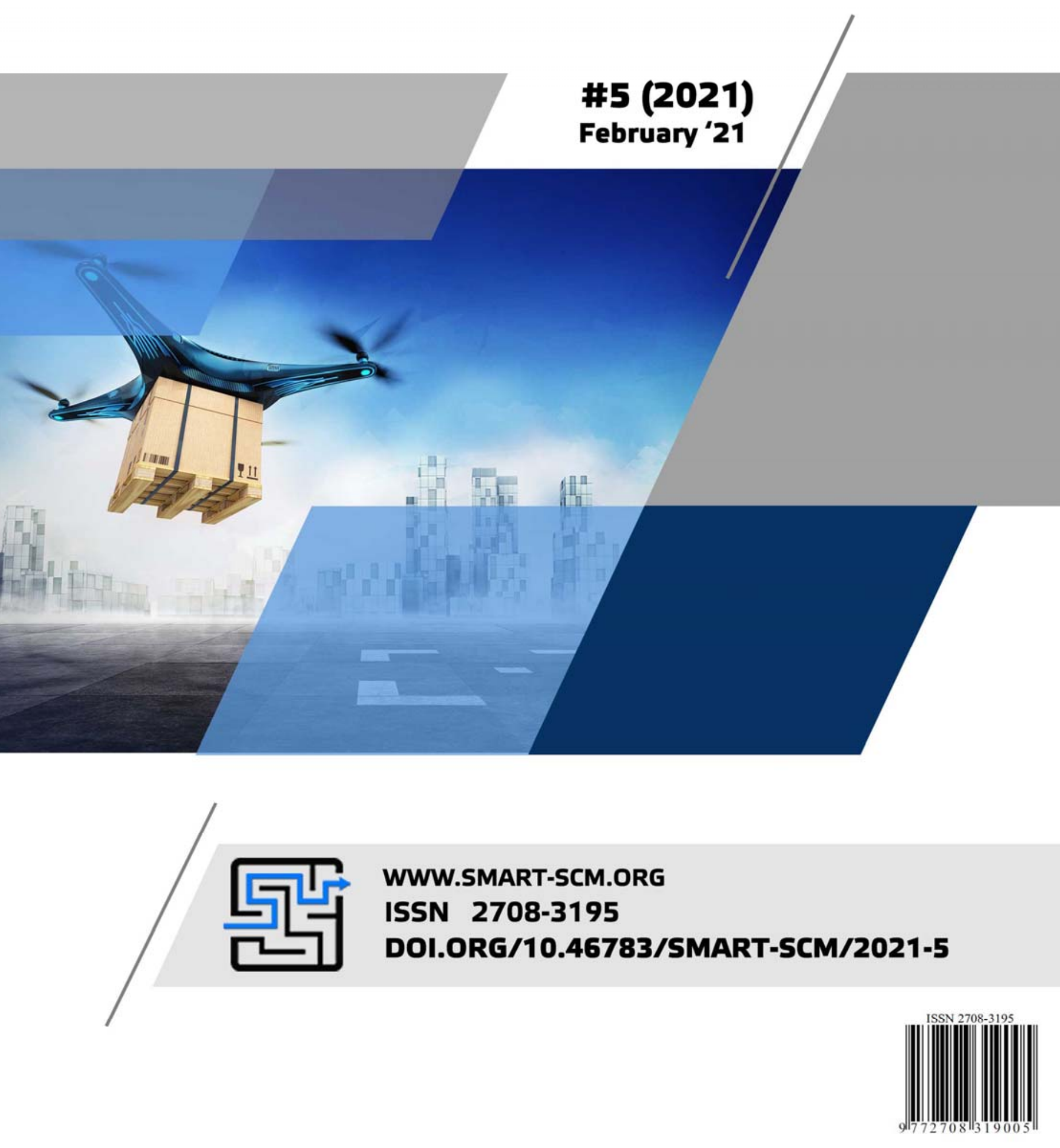




\section{Electronic scientific and practical collection
INTELLECTUALIZATION OF LOGISTICS
AND SUPPLY CHAIN MANAGEMENT}

Electronic scientific and practical publication in economic sciences

ISSN 2708-3195

DOl: https://doi.org/10.46783/smart-scm/2021-5

Released 6 times a year

№ 5 (2021)

February 2021

Kyiv - 2021 
Founder: Viold Limited Liability Company

Editor in Chief:

Deputy editors-in-chief:

Technical editor:

Executive Secretary:
Hryhorak M. Yu. - Doctor of Economics, Ass. Professor.

Koulyk V. A. - PhD (Economics), Professor.

Marchuk V. Ye. - Doctor of Tech. Sci., Ass. Professor.

Harmash O. M. - PhD (Economics), Ass. Professor.

Davidenko V. V. - PhD (Economics), Ass. Professor.

\section{Members of the Editorial Board:}

SWIEKATOWSKI Ryszard - Doctor of Economics, Professor (Poland);

POSTAN M. Ya. - Doctor of Economics, Professor;

TRUSHKINA N. V. - PhD (Economics), Corresponding Member of the Academy;

KOLOSOK V. M. - Doctor of Economics, Professor;

ILCHENKO N. B. - Doctor of Economics, Ass. Professor;

SOLOMON D. I. - Doctor of Economics, Professor (Moldova);

ALKEMA V. H. - Doctor of Economics, Professor;

Henryk DŹWIGOŁ - PhD (Economics), Professor (Poland);

SUMETS O. M. - Doctor of Economics, Ass. Professor;

STRELCOVÁ Stanislava - PhD (Economics), Ass. Professor, (Slovakia);

RISTVEJ Jozef (Mr.) PhD (Economics), Professor, (Slovakia);

ZAMIAR Zenon - Doctor of Economics, Professor, (Poland);

SMERICHEVSKA S. V. - Doctor of Economics, Professor;

GRITSENKO S. I. - Doctor of Economics, Professor;

KARPENKO O. O. - Doctor of Economics, Professor;

PATKOVSKYI S. A. - Business practitioner.

The electronic scientific and practical journal is registered in international scientometric data bases, repositories and search engines. The main characteristic of the edition is the index of scientometric data bases, which reflects the importance and effectiveness of scientific publications using indicators such as quotation index, h-index and factor impact (the number of quotations within two years after publishing).

In 2020, the International Center for Periodicals (ISSN International Center, Paris) included the Electronic Scientific and Practical Edition "Intellectualization of Supply Chain Management" in the international register of periodicals and provided it with a numerical code of international identification: ISSN 2708-3195 (Online).

Recommended for dissemination on the Internet by the Academic Council of the Department of Logistics NAU (No. 7 of February 26, 2020). Released 6 times a year. Editions references are required. The view of the editorial board does not always coincide with that of the authors.

t.me/smart_scm facebook.com/Smart.SCM.org twitter.com/ScmSmart

DOI: https://doi.org/10.46783/smart-scm/2021-5 e-mail: support@smart-scm.org тел.: (063) 593-30-41

https://smart-scm.org 


\section{Contents}

HRYHORAK M.Yu. Doctor of Economics, Associate Professor, Head of Logistics Department National Aviation University (Ukraine), Henryk DŹWIGOŁ PhD DSc, Associate professor, Professor - Organization and Management Silesian University of Technology in Gliwice (Poland), TRUSHKINA N.V. PhD (Economics), Associate Professor, Senior Research Fellow, Regulatory Policy and Entrepreneurship Development Institute of Industrial Economics of the National Academy of Sciences of Ukraine (Ukraine), SHKRYGUN Yu.O. Postgraduate of Industrial Economics of the National Academy of Sciences of Ukraine (Ukraine) SUBSTANTIATION OF EXPEDIENCY OF THE COMPLEX APPROACH FOR SUPPLY CHAINS MANAGEMENT IN THE COVID-19 CONDITIONS

ROMANENKOV Yu.A. Doctor of Technical Science, Professor, Professor of Management Department National Aerospace University "Kharkov Aviation Institute" (Ukraine), Yashar RAHIMI Software Engineering Department of National Aerospace University "Kharkov Aviation Institute" (Ukraine), DANOVA Mariia PhD (Technical Science), Associate Professor, Associate Professor of Software Engineering Department of National Aerospace University "Kharkov Aviation Institute" (Ukraine), FEOKTYSTOVA Olena PhD (Technical Science), Associate Professor, Associate Professor of Management Department National Aerospace University "Kharkov Aviation Institute" (Ukraine), SHOSTAK I.V. Doctor of Technical Science, Professor, Professor of Software Engineering Department of National Aerospace University "Kharkov Aviation Institute" (Ukraine) APPROACH TO INTELLECTUALIZATION OF COMPLETE SUPPLY CHAIN MANAGEMENT PROCESSES USING FUZZY EXPERT SYSTEMS

HRYHORAK M. Yu. Doctor of Science in Economics, Associate Professor, Head of Logistics Department of National Aviation University (Ukraine), SHEVCHUK L.V. Students of Logistics Department National Aviation University (Ukraine) EFFICIENCY OF "LEAN MANAGEMENT" APPLICATION IN BUSINESS PROCESSES MANAGEMENT OF REFRIGERATION EQUIPMENT SUPPLY CHAIN DURING THE COVID CRISIS

SUMETS O.M. Doctor of Economics, Professor, Professor of National University of Pharmacy (Ukraine)

\section{EVALUATION OF THE INVESTMENTS EFFICIENCY IN THE DEVELOPMENT OF THE KEY} COMPONENT OF THE SUPPLY CHAIN

SEMERIAHINA M. M., Senior Lecturer of Logistics Department, National Aviation University (Ukraine), HRYHORAK M. Yu. Doctor of Science in Economics, Associate Professor, Head of Logistics Department of National Aviation University (Ukraine) THE ROLE OF THE AIRLINE AS A LOGISTICS PROVIDER IN THE PASSENGER TRAVEL CHAINS INVOLVING AIR TRANSPORT 
UDC 339.137.2:334.716:005.95

DOI: https://doi.org/10.46783/smart-scm/2021-5-3

JEL Classification: L10, M11, M12.

Received: 14 February 2021

Hryhorak M.Yu. Doctor of Economics, Associate Professor, Head of Logistics Department National Aviation University (Ukraine)

ORCID - 0000-0002-5023-8602

Researcher ID -

Scopus author id: -57208222758

Shevchuk L.V. Students of Logistics Department National Aviation University (Ukraine)

ORCID -

Researcher ID -

Scopus author id: -

\title{
EFFICIENCY OF "LEAN MANAGEMENT" APPLICATION IN BUSINESS PROCESSES MANAGEMENT OF REFRIGERATION EQUIPMENT SUPPLY CHAIN DURING THE COVID CRISIS
}

\begin{abstract}
Mariia Hryhorak, Shevchuk Liliya "Efficiency of "lean management" application in business processes management of refrigeration equipment supply chain during the COVID crisis". The article reveals the main trends in the functioning of global supply chains in the context of the COVID-19 pandemic and their impact on the activities of Ukrainian enterprises are identified. It is noted that the closure of borders between countries and the introduction of self-isolation regime caused a significant reduction in production capacity and the volume of international trade. Global supply chains have become very vulnerable and necessitate their revision and the search for alternative ways to deliver goods to end users. Since Ukraine is a country with an open market economy, this article summarizes the main challenges for import-dependent supply chains and makes proposals on ways to overcome them. The expediency of applying the concept of Leanmanagement in business processes management of refrigeration supply chains during a pandemic as a means of overcoming crisis situations and ensuring sustainable development are proved. The dynamics and structure analysis of the company LLC "Holod Engineering" income and expenses allowed to establish a tendency to reduce the profitability of the company's business and capital turnover, as well as increase the share of logistics costs in the production costs. The greatest impact on the growth of logistics costs have the inventory costs due to the processes of storage and orders completion and delivery delays, which lead to customer dissatisfaction and complaints. Methodical approaches to estimating the level of processes coordination in the supply chains of refrigeration equipment, calculation of supply lots optimal parameters, levels of raw materials and components stocks, production and storage capacity rationalization of the enterprise are substantiated. With the help of Shewhart's control charts, the coordination of business processes in the equipment supply chains were assessed and the sources of potential losses were identified. The technological and logistics processes optimization in terms of their cost, duration and quality of results takes into account not only individual processes of enterprises, but also interprocess connections between supply chain links. It is proposed to implement a number of organizational measures using the concept of lean management, which involves market integration, production process, procurement and sales in order to provide a high level of customer
\end{abstract}


service. The efficiency of the proposed organizational changes and their impact on business profitability, inventory turnover, the amount of logistics costs and the quality of customer service are determined.

Keywords: supply chain management, business process, lean management, lean supply chain, cost management.

Мрія Григорак, Шевчук Ліля "Ефективність застосування "бережливого управління" в управлінні бізнес-прочесами ланцюга постачання холодильного обладнання під час кризи COVID". У cmammі розкрито основні тенденції у функціонуванні глобальних ланцюгів постачання в умовах пандемії COVID-19 та визначено їх вплив на діяльність українських підприємств. Відзначено, що закриття кордонів між країнами та введення режиму самоізоляиії спричинили значне скорочення виробничих потужностей і обсягів міжнародної торгівлі. Глобальні ланцюги постачання стали дуже вразливими і обумовлюють необхідність їх перегляду та пошуку альтернативних шляхів доставки товарів до кінчевих споживачів. Оскільки Україна є країною з відкритою ринковою економікою, то в даній статті узагальнено основні виклики для імпортозалежних ланцюгів постачання та зроблено пропозичії щодо шляхів їх подолання. Доведено доцільність застосування концепції Leanменеджменту в управлінні бізнес-прочесами ЛП холодильного обладнання під час пандемії як засобу виходу з кризових ситуачій та забезпечення сталого розвитку. Аналіз динаміки і структури доходів і витрат підприємства ТОВ «Холод-інжиніринг» дозволив встановити тенденцію до зменшення прибутковості бізнесу компанії і оборотності капіталу, а також збільшення частки логістичних витрат в собівартості продукції. Найбільший вплив на зростання логістичних витрат мають витрати на утримання запасів, що обумовлено прочесами зберігання і комплектації замовлень $і$ затримками в доставках, що призводять до незадоволеності і скарг клієнтів. Обгрунтовано методичні підходи до оцінювання рівня скоординованості прочесів в ланцюгах постачання холодильного обладнання, розрахунку оптимальних параметрів партій постачання, рівнів запасів сировини і комплектуючих, рачіоналізачії використання виробничих та складських потужностей підприємства. За допомогою контрольних карт Шухарта зроблено очінку скоординованості бізнеспрочесів в ланцюгах постачання обладнання та визначено джерела потенційних втрат. Оптимізачія технологічних та логістичних прочесів за їх вартістю, тривалістю та якістю результату враховує не лише окремі прочеси підприємств, а й міжпрочесні зв'язки між ланками ланцюгів постачання. Запропоновано здійснити ряд організаційних заходів з використанням концепиії lеап-менеджменту, що передбачає об'єднання ринку, виробничого прочесу, закупівель $i$ збуту з метою високого рівня обслуговування клієнтів. Визначено ефективність запропонованих організаційних змін та їх вплив на прибутковість бізнесу, оборотність запасів, величину логістичних витрат та якість обслуговування споживачів.

Ключові слова: управління ланцюгами постачання, бізнес-процес, lean-менеджмент, leanланцюг постачання, управління витратами.

Мария Григорак, Шевчук Лиля " Эффективность применения "бережливого управления" в управлении бизнес-процессами цепи поставки холодильного оборудования во время кризиса COVID ". В статье раскрыты основные тенденции в функционировании глобальных цепей поставок в условиях пандемии COVID-19 и определено их влияние на деятельность украинских предприятий. Отмечено, что закрытие границ между странами и введение режима самоизолячии вызвали значительное сокращение производственных мощностей и объемов международной торговли. Глобальные чепи поставок стали очень уязвимыми и обусловливают необходимость их пересмотра и поиска альтернативных путей доставки товаров до конечных потребителей. Поскольку Украина является страной с открытой рыночной экономикой, то в данной статье обобщены основные вызовы для импортозависимых чепей поставок и сделаны предложения о путях их преодоления. Доказана иелесообразность применения концепиии Lean-менеджмента в управлении бизнеспрочессами ЦП холодильного оборудования во время пандемии как средство выхода из кризисных ситуачий и обеспечения устойчивого развития. Анализ динамики и структуры доходов и расходов предприятия ООО «Холод-инжиниринг» позволил установить тенденцию к уменьшению прибыльности бизнеса компании и оборачиваемости капитала, а также увеличение доли 
логистических затрат в себестоимости продукции. Наибольшее влияние на рост логистических издержек имеют расходы на содержание запасов, что обусловлено прочессами хранения и комплектации заказов и задержками в поставках, приводящие к неудовлетворенности и жалобам клиентов. Обоснованы методические подходы к оченке уровня скоординированности процессов в чепях поставок холодильного оборудования, расчета оптимальных параметров партий поставки, уровней запасов сырья и комплектующих, рачионализации использования производственных и складских мощностей предприятия. С помощью контрольных карт Шухарта произведена оченка скоординированности бизнес-прочессов в цепях поставок оборудования и определены источники потенциальных потерь. Оптимизачия технологических и логистических прочессов по их стоимости, продолжительности и качеству результата учитывает не только отдельные прочессы предприятий, но и межпрочессные связи между звеньями чепей поставок. Предложено осуществить ряд организационных мероприятий с использованием концепции lеап-менеджмента, что предусматривает объединение рынка, производственного процесса, закупок и сбыта с челью высокого уровня обслуживания клиентов. Определена эффрективность предложенных организачионных изменений и их влияние на прибыльность бизнеса, оборачиваемость запасов, величину логистических издержек и качество обслуживания потребителей.

Ключевые слова: управление цепочками поставок, бизнес-процесс, lean-менеджмент, leanцепь поставок, управление затратами.

Introduction. Global pandemic, due to the rapid spread of the rapid spread of the Covid-19 virus has exacerbated global and regional economic development challenges. In addition to the usual negative factors associated with the existence of military conflicts, the introduction of mutual trade restrictions, which contradicts the principles of open markets and free competitive access, climate change and increasing the frequency of extreme weather events, additional quarantine restrictions cause significant risks in global supply chain management, reduce their stability and change the configuration. Thus, the introduction of lockdown, closure and reopening of production centers in China has significantly affected the relationship between suppliers, manufacturers and consumers. The authors [1] defined such a state as the supply side shock for European and American companies. Consumer needs have changed significantly: in the conditions of quarantine measures and teleworking, the demand for food, household and medical goods, Internet communication and electronic means of communication has increased.

An interesting study of the company's activities concluded that in the post-Covid period supply chains will be revised not to reduce costs, but to achieve greater sustainability, which will lead to diversification of production, storage and procurement, as well as the return of production from abroad and the active use of outsourcing in the near abroad [2]. The authors emphasize the need to reorganize workplaces in accordance with the requirements of social distancing and hygiene, which determines the feasibility of digitization and automation of existing processes in supply chains and, accordingly, adaptation to new standards: in particular, provide one-way freight systems packing areas in compliance with the requirements of social distancing.

This indicates the relevance of research on the impact of these geoeconomic changes on business processes in supply chains, the search for new methodological approaches to their optimization and the organization of cross-functional interaction of business partners to reduce logistics costs and increase sustainability.

The experience of leading companies shows that synchronization of processes and effective partnership in supply chains reduces delays in the delivery of goods and creates added value for customers. One of the effective mechanisms to improve the efficiency and effectiveness of supply chains is lean-management, the essence of which is 
that all participants in the supply chain try to reduce their costs while increasing the speed and flexibility of doing business. That is, there is a directly proportional relationship - the more flexible business processes in supply chains, the better the performance of all its participants. As the functioning of specific supply chains is influenced by various factors of the external and internal environment, there is a need to quickly find opportunities to improve business processes and increase the stability of the management system. High adaptability, economy of the supply chain and speed of decision-making, which is formed during the introduction of leanmanagement tools, will allow the business to survive. Thus, the trends outlined above, respectively, determined the topic of the study.

Analysis of research problems. Problems of efficiency of management of financial, material and information flows from the supplier to the final consumer in SC are deeply investigated by leading foreign and domestic scientists, in particular, M. Linders, H. Firon, V. Sergeev, E. Krykavsky, N. Chukhrai, T. Kolodizeva and others. Among the recent publications used in the preparation of this article, it should be noted the scientific works of N. Bocharova, S. Dubovik, H. Sigida [4; 5], and foreign, J. Ganstedt, K. Lysons, M. Reynolds $[6 ; 7 ; 8]$, scientists.

Most experts believe that the concept of lean is based on the ideas of Kaizen, but it has a wider application in SC, as it focuses on optimizing the processes of the entire supply chain. Thus, R. Shah and P. Ward [14, p.55] highlight the following positive effect of the introduction of LEAN-concept in SC: statistical control of processes; reduction of time for reconfiguration; feedback from suppliers; consumer involvement; introduction of PULLsystem; flow continuity.

Thus, if we consider lean as a philosophy, as a well-thought-out and tested optimization, cooperation with customers and suppliers on the basis of partnership, mutual assistance in solving problems, then it can be an effective solution in such a difficult situation. The implantation of lean-practice helps to organize a steady flow in SC, and enterprises to become both innovative, competitive and more stable in rapidly changing conditions. This, in turn, has increased interest in the concept of lean by domestic companies, most of which have suffered significant losses during the crisis and are looking for alternative sources to increase business profitability.

While some companies have suffered significant losses during the pandemic, there are a number that have successfully passed the adaptability test and taken a decisive step forward. Most of these companies use and continue to implement quality management tools and lean management techniques. An example of such companies is the worldfamous clothing and fashion retail chain Zara, which, despite declining demand for industrial products, thanks to wellestablished processes, fixed principles of economy and flexibility, was able to withstand difficult modern conditions and increase the efficiency of SC [13].

Many domestic authors and foreign scholars agree that it is possible to gain significant benefits associated with the introduction of lean management methods in crisis conditions. D. Demakhin noted that Toyota's production system, which is based on the principles of lean strategy, arose just in response to the crisis and since its inception is anti-crisis, which confirms the feasibility and effectiveness of its implementation [9]. M. Ballet, Lean author, Lean coach and cofounder of Lean Institut France, considers the feasibility of applying the concept: "When a business is in a crisis, we need to change the way of thinking to Lean-style thinking to find a way out" [10]. In the works of G.Tkachenko the advantages of implementing the Lean concept are noted, which are that "Lean implementation is aimed at optimizing the processes of the entire supply chain" [11]. Due to the implementation of the principles of Lean-management, it is possible to find bottlenecks and identify processes that do not create added consumer value, but only 
burden SC with unproductive costs, which is especially relevant in the current unstable conditions.

M. Porter in his research found that the company can gain additional competitive advantages by increasing process productivity and minimizing costs, which in turn will increase competitive position in the market and ensure economic stability, which is especially important in a pandemic conditions. Lean Global Network (LGN) research shows that the positive factors behind the introduction of the lean concept are the system of continuous improvement, which means that the company constantly improves its performance indicators, such as [12]: reduction production time by 2-3 times; increase in inventory turnover by 1.5-2 times; increase the return on investment by 3 times.

Therefore, an integrated approach using Lean-management takes to a qualitatively new level of supply chain management with the aim of creating a more efficient and sustainable SC. At the same time, despite the sufficiently developed issues of optimizing the management of business processes of the SC, it requires a broader theoretical and practical study of the SC development and its functioning in crisis conditions of a pandemic. Because, cost-effective strategies and program of events in supply chain management are needed to be able to hold on to the positions that a lean concept can serve.

Purpose and objectives of the article. The aim of the study is to generalize transformational changes in supply chain management under the influence of a global pandemic improving the business process management system in the supply chain of refrigeration equipment based on the concept of lean management to reduce overall logistics costs.

Basic material and results. Ukraine is a country with an open market economy, and therefore dependent on the global system of trade. Export- and import-oriented supply chains of domestic producers were significantly affected by global factors and led to a substantial reduction in production by individual industries. Table 1 identifies five key pandemic challenges for Ukrainian enterprises and summarizes possible ways to overcome these challenges, taking into account the concept of Lean Supply Chain.

Consequently, the main purpose of using the concept of Lean Supply Chain is to use savings tools to implement organizational and economic activities to increase the competitiveness of domestic enterprises in regional and global supply chains. To gain a competitive advantage in the new postpandemic economic environment of trade movement, it is necessary to combine partnerships to reduce levels of uncertainty and risk, as well as to reorganize internal business processes. Note that the imperfect operating activities of Ukrainian enterprises leads to a lack of profit in the supply of products to foreign markets, also to the increase in costs of importing goods associated with significant dependence on logistics decisions of logistics service providers, which are not always focused on domestic processes.

Consider in more detail the activities of the Ukrainian company LLC "HolodEngineering", which specializes in providing services for the supply of industrial, commercial, agricultural and technological refrigeration equipment in the Ukrainian market. The main consumers (customers) of products (services) are enterprises of various activities, from farms, shops to large retail chains and industrial enterprises, such as: LLC "Novus", LLC "ATB", LLC "Ostersky meatpacking plant" , LLC "Zhytomyr Dairy", JSC "Roshen", LLC "Upscale Logistics" and many others [15]. 
Table 1. Challenges of the global pandemic for SC and ways to overcome them

\begin{tabular}{|l|l|l|}
\hline № & \multicolumn{1}{|c|}{ Challenges } & \multicolumn{1}{c|}{ Ways to solve } \\
\hline 1 & $\begin{array}{l}\text { The risk of weak players } \\
\text { leaving the market. }\end{array}$ & $\begin{array}{l}\text { - Introduce a policy of continuous improvement, risk monitoring and } \\
\text { appropriate corrective action to quickly eliminate and identify the root } \\
\text { causes of problems. } \\
\text { - Identify the most important links and bottlenecks in the SC, their } \\
\text { possible sources of optimization and minimization of losses. }\end{array}$ \\
\hline 2 & $\begin{array}{l}\text { Failures and delays in global } \\
\text { enterprise supply networks } \\
\text { due to quarantine restrictions. }\end{array}$ & $\begin{array}{l}\text { Establish a strategy for continuous lean extraction, by introducing } \\
\text { a continuous flow of goods in chains, in order to reduce failures and } \\
\text { delays. } \\
\text { - Align the takt time with the customer's expectations and optimize } \\
\text { the duration of the logistics cycle. }\end{array}$ \\
\hline 3 & $\begin{array}{l}\text { Increased costs for supply, } \\
\text { production and sales. }\end{array}$ & $\begin{array}{l}\text { Using Lean's main tools, identify value-added streams and } \\
\text { activities that consume resources but do not create value for } \\
\text { consumers. } \\
\text { - Standardize the algorithm of actions at each stage of the goods or } \\
\text { services movement in the chain, to minimize all possible losses }\end{array}$ \\
\hline 4 & The uneven demand. & $\begin{array}{l}\text { - Carry out constant monitoring of demand and act in accordance } \\
\text { with consumer behavior. } \\
\text { - Evaluate the available inventory, to maintain business continuity, } \\
\text { in accordance with consumer demand. } \\
\text { - Introduce a flow quality control system at each stage of goods or } \\
\text { services movement in the chain. }\end{array}$ \\
\hline 5 & $\begin{array}{l}\text { Low adaptability and crisis } \\
\text { response of SC. Implement the system of adaptation and rapid readjustment, for a } \\
\text { flexible production process depending on changing market demand } \\
\text { conditions. } \\
- \text { Conduct research on the flow of value creation and stress testing } \\
\text { of SC with the aim of continuous improvement. }\end{array}$ \\
\hline
\end{tabular}

Source: Generalized by the author on the basis [1-3].

The main competitive advantages of Holod -Engineering are availability of highly qualified professionals and engineering staff that provides support to its partners at all stages from order design to post-warranty and after-sales service, the status of a comprehensive supplier of equipment and high-tech turnkey design solutions focused on individual customer needs. It should be noted that the market of refrigeration equipment in Ukraine is currently developing dynamically. This is facilitated by the constant increase in demand for products from the food processing industry. Most companies in this industry are dominated by outdated refrigeration equipment, which needs to be upgraded to store finished products. Trading companies are also constantly increasing the capacity of refrigeration chambers using industrial cold.

Thus, the existing competitive advantages and stable demand for the products LLC "Holod-Engineering" ensure the company's profitability. At the same time, the analysis of financial indicators for the last five years revealed a trend of decreasing net profit, which indicates a decrease in operating efficiency (Fig. 1). 


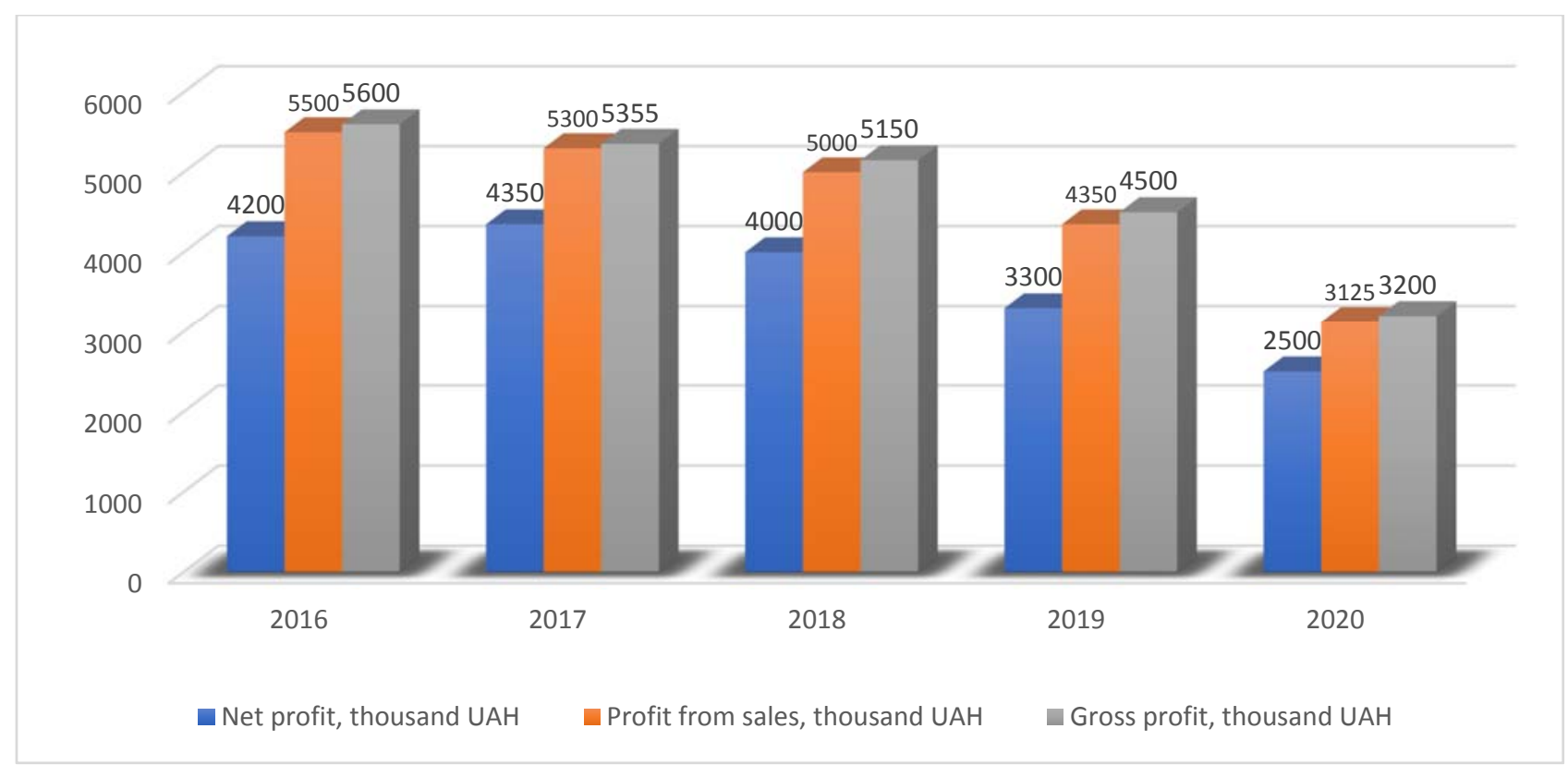

Figure 1 - Dynamics of profit indicators of LLC " Holod Engineering" for 2016-2020

Therefore, the presence of internal factors, such as rising costs for the purchase, transportation and storage of components, as well as the impact of external factors related to the effects of the global pandemic, necessitated of business processes reengineering in refrigeration supply chains. That is why the main purpose of the study was to find ways of revolutionary elimination of crisis phenomena, create the conditions and maintain a system of business performance continuous improvement.

Figure 2 graphically shows the influence of external and internal factors on the formation of competitive advantages of the company, among which the most important is the level of interaction between the departments of supply, sales and production infrastructure, which directly affects the speed of response to changes in market trends (Fig. 2). It was also found that significant losses in the company's efficiency were due to the supply of low quality raw materials.
The analysis of the refrigeration equipment supply chains configuration allowed to identify and assess the impact on their operation efficiency of the following factors:

- procurement processes efficiency and interaction with suppliers,

- costs for the purchase and stocks storage,

- quality of incoming raw materials and equipment, time,

- delivery time and order execution

- the cost of manufactured parts and equipment,

- quality of internal production operations and equipment operation reliability,

- demand for manufactured products, cost and equipment quality,

- market segment, economic and political situation. 


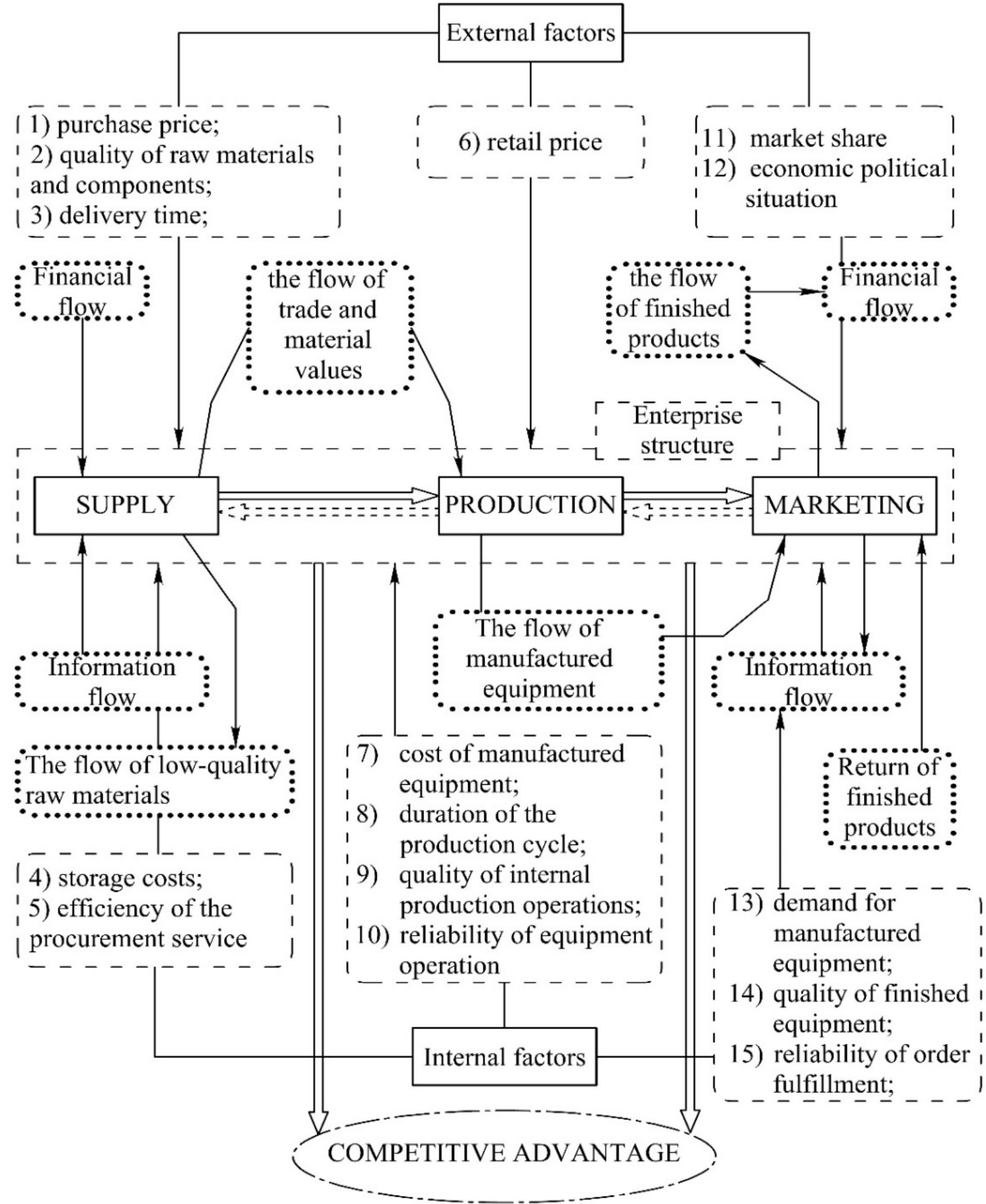

Figure 2 - Influence of external and internal factors on the business processes organization in the LLC " Holod Engineering" supply chain

LLC "Holod Engineering", like most manufacturing companies, works on the principle of custom production. In this case, delivery plans are quite a conditional document, because the bulk of material resources are obtained quickly (as orders are received). Figure 3 schematically shows the main business processes associated with consumer orders execution. 


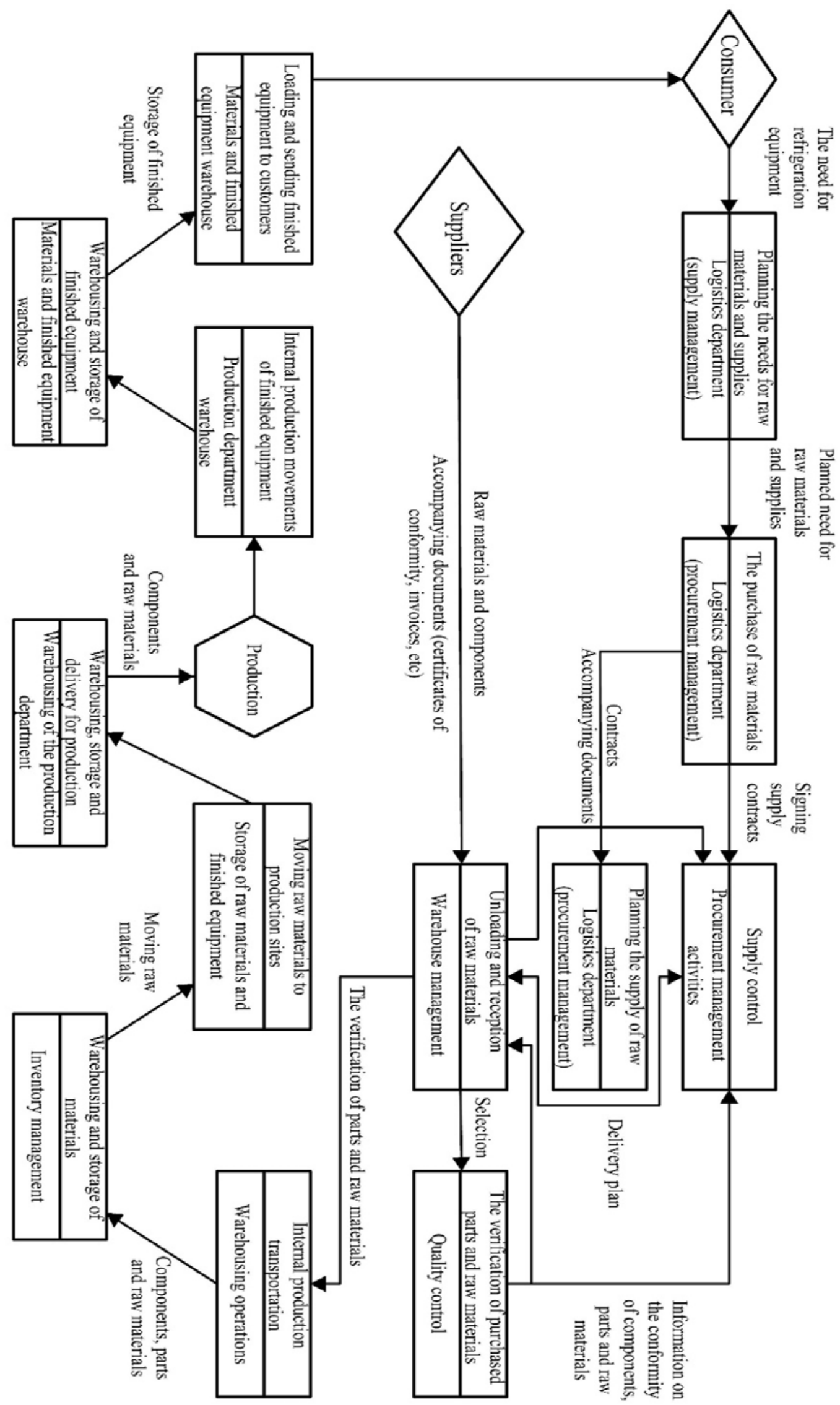

Figure 3 - The interrelations and mutual influences scheme of business processes in LLC "Holod Engineering" refrigerating equipment supply chains 
As a result of the refrigeration equipment supply chain analysis at the enterprise, the following bottlenecks were identified:

1) reduction of inventory turnover associated with falling sales of the enterprise, which leads to an increase in storage costs and an increase in losses due to the freezing of working capital;

2) problems with inventory planning, which lead to the accumulation of their volumes, also in warehousing operations activities and lack of storage space;

3) lack of an effective planning system, sales analysis and monitoring of resource balances in the warehouse, leads to errors in the procurement management of material resources and components. This bottleneck leads to unnecessary costs for the urgent purchase of additional resources and thereby increase the duration of the order;

4) Non-liquid stock accumulation that exceeded the normal stay period in the warehouse. The reason for this bottleneck is errors in forecasting and calculating the required batches of materials, and because of falling demand, which is observed in recent years of the enterprise.

Lean tools were used to cover the identified bottlenecks, which include the search for alternative savings sources, minimization of possible losses with limited market capacity and the inability to increase equipment sales. For this purpose, a complex of mathematical models to substantiate logistics decisions was developed, related to the choice of suppliers, to determining the optimal delivery batch size and the minimum and maximum stocks levels, placement in the warehouse and warehousing processes optimization (Table 2).

The result of the implementation of the tasks is a built-in extraction strategy, which unites all enterprises involved in the flow of value creation of refrigeration equipment. For its successful implementation it is recommended to introduce a quick and flexible response, as follows:

- association of all business processes participants on the "win-win" principle for mutual information exchange and receiving the maximum benefits;

- use of modern information and communication technologies (barcode scanner and electronic data interchange);

- optimization of internal business processes: visual management; additional marking of goods and work areas; minimization of unnecessary intra-warehouse movements of goods and staff; automatic replenishment of orders, etc.;

determination of stock storage standards, monitoring of their condition in real time, clear instructions on work with illiquid stocks and their prevention;

- zoning of warehouses and production areas on the "hot and cold zones" principle;

- formation of direct channels of communication with consumers, using databases to evaluate customers and formation of loyalty programs.

The implementation of the proposed measures allows to obtain the following intermediate results:

introduction of logistics costs monitoring, timely analysis of deviations "plan-fact" and cost structure for logistics operations increases the accuracy of forecasting the company financial results, promptly manage liquidity and inventory turnover, develop measures to reduce accounts receivable;

- optimization of spare parts supply lots and rationing of maximum and minimum levels of stocks allows to reduce the share of costs for their maintenance by $8.99 \%$ per month in the goods sold cost;

- The Lean-management and 5S principles introduction, minimizes the risks of creating excess stocks, which will save the company about 3 million UAH per year;

- standardization of warehouse processes contributes to an increase in labor productivity in order picking by $16 \%$, reducing the duration and cost of processing one unit of goods by $2.5 \%$;

- due to optimization the volumes and structure of refrigeration equipment components stocks and rationalization of 
their placement in a warehouse it is possible to release to $30 \%$ of warehouse areas of the enterprise.

Table 2. The list of actual tasks to increase the business processes efficiency in LLC "Holod Engineering" SC and methodical approaches to their decision

\begin{tabular}{|c|c|c|}
\hline № & Actual tasks & Integral indicators \\
\hline 1. & & Supply management improvement \\
\hline 1.1. & $\begin{array}{l}\text { Suppliers evaluation } \\
\text { and selection. }\end{array}$ & $\begin{array}{l}\text { OTIF }=\frac{\sum N_{t}}{\sum N_{o}} \text {, where OTIF - business process management system "In } \\
\text { time in full", Nt - the quantity of goods delivered on time; No - the total } \\
\text { quantity of the ordered goods [16]. }\end{array}$ \\
\hline 1.2 . & $\begin{array}{l}\text { Improved algorithm of } \\
\text { the material resources } \\
\text { procurement process } \\
\text { in terms of } \\
\text { procurement planning. }\end{array}$ & $\begin{array}{l}E O Q=\sqrt{\frac{2 * 3 * C_{i}}{C_{2}}} \text {, where } \mathrm{EOQ} \text { - the optimal batch size of the products } \\
\text { supply to the enterprise; } 3 \text { - sales volume of products in this period; } \mathrm{Ci} \text { - the } \\
\text { average cost of placing one order; } \mathrm{C} 2 \text { - the cost of maintaining a unit of } \\
\text { product in this period [17]. }\end{array}$ \\
\hline 2 & & Inventory management system improvement \\
\hline 2.1. & $\begin{array}{l}\text { Division of stocks into } \\
\text { groups. }\end{array}$ & $\begin{array}{l}\text { Analysis of stocks by the } A B C \text { method and their division into groups } \\
\text { according to the Pareto } 80 / 20 \text { principle ( } 80 \% \text { - revenue, form } 20 \% \text { - stocks). }\end{array}$ \\
\hline 2.2. & $\begin{array}{l}\text { Algorithm for working } \\
\text { with illiquid stocks. }\end{array}$ & $\begin{array}{l}Z=\frac{N}{\mathrm{C}}, \text { where } \mathrm{Z} \text { - the percentage of inventories in the cost per month; } \mathrm{N}- \\
\text { total amount of stocks; } \mathrm{C} \text { - finished product cost, } \% \text {. [18, p.77] }\end{array}$ \\
\hline 3 & \multicolumn{2}{|c|}{ Optimization of the warehousing system and production areas placement. } \\
\hline 3.1. & $\begin{array}{l}\text { Organization of } \\
\text { storage areas and } \\
\text { production areas. }\end{array}$ & $\begin{array}{l}n=\frac{D T(1+S)}{V}, \text { where } n \text { - number of kanban cards (pcs.); DT - projected } \\
\text { demand during the order fulfillment period (pcs.); D - the number of parts } \\
\text { that are delivered to the next section per unit time (pcs.); } T \text { - order } \\
\text { fulfillment time (hrs); } S \text { - insurance stock, as a percentage of demand for } \\
\text { the period of order fulfillment (\%); } V \text { - the container volume for transporting } \\
\text { parts (m3) [19, p.85]. }\end{array}$ \\
\hline 4 & \multicolumn{2}{|r|}{ Optimization of logistics cost management } \\
\hline 4.1. & $\begin{array}{l}\text { Information processing } \\
\text { on logistics costs and } \\
\text { their optimization. }\end{array}$ & $\begin{array}{l}\text { Comparison with Shewhart's control cards "as is" and projected "as it } \\
\text { should be", according to the logistics costs indicators of the enterprise [20, } \\
\text { p.169]. }\end{array}$ \\
\hline 5 & \multicolumn{2}{|r|}{ End-user demand analysis. } \\
\hline 5.1. & $\begin{array}{l}\text { Work with sales and } \\
\text { operational planning. }\end{array}$ & $\begin{array}{l}\text { Коефіцієнт сервісу як вартість загальних поставок за місяць } \\
\text { в порівнянні з вартістю загальних замовлень за місяць } \\
C S \%=\frac{\sum o_{r}+O_{s h}}{C_{o}} \text {, where } C S \% \text { - coefficient of service as the cost of total } \\
\text { deliveries per month compared to the cost of total orders per month; } \mathrm{O}_{r} \text { - } \\
\text { orders received; } \mathrm{O}_{s h} \text { - orders shipped; } \mathrm{C}_{0} \text { - cost of all orders [18,p.27]. }\end{array}$ \\
\hline
\end{tabular}

Consequently, through the proposed organizational measures, the company LLC "Holod Engineering" will be able to increase the profitability of its own business, and create new competitive advantages in unstable, rapidly changing conditions. The proposed methodological provisions for reengineering business processes in the refrigeration equipment supply chain using the Lean-concept have significantly improved the various departments coordination of the enterprise, to improve the customer service quality, synchronize the supply, production and marketing of products, reduce total 
logistics costs by making optimized logistics solutions.

Conclusions. In the course of the study, the expediency of business processes integrated management in the refrigeration equipment supply chains, in the context of instability and risks associated with the global coronavirus pandemic was substantiated. The generalization of global trends, conditions of external and internal environments made it possible to conclude that it is necessary to constantly improve both individual business processes in supply chains and their coordination and synchronization in real time using the Lean Supply Chain concept.

The analysis of refrigeration equipment SC configuration for the company LLC "Holod Engineering" revealed weaknesses associated with a decrease in asset turnover, ineffective procurement planning and the lack of an effective inventory management system. The dynamics and structure analysis of income and expenses revealed a downward trend in profitability of the company's business, and also showed a significant share in their structure of logistics costs and inventory costs due to losses in storage and ordering as a consequence to delays in delivery, leading to customer dissatisfaction and complaints. To improve the business process management system in the supply chain of LLC "Holod Engineering", to undertake a number of activities using the lean management concept, which involves market, production process, procurement and sales integration for high quality customer service level were proposed.

It is proved that the advantages of the lean tools introduction are the potential losses minimization, increasing the production productivity and warehousing operations of the company. With the help of Shewhart's control charts, the coordination of business processes in the equipment supply chains was assessed and the sources of potential losses were identified. The methodical approach and a complex of administrative decisions which have allowed to calculate optimum processes parameters of raw materials purchases, stocks levels and conditions of their placement in a warehouse of the enterprise are developed. Optimization of technological and logistics processes in terms of their cost, duration and quality of results takes into account not only individual processes of enterprises, but also interprocess connections between supply chain links.

\section{References}

1. Baldwin R., Freeman R. (2020). Supply chain contagion waves: Thinking ahead on manufacturing 'contagion and reinfection' from the COVID concussion. Available at https://voxeu.org/article/covid-concussion-and-supply-chain-contagion-waves (accessed 23.12.2020)

2. Post-Coronavirus Supply Chain Recovery. (2020). THE JOURNEY TOWARDS THE NEW NORMAL. Available at https://www.dhl.com/content/dam/dhl/global/core/documents/pdf/glocore-post-covid-eme-white-paper.pdf (accessed 23.12.2020)

3. Logistics trends of 2020-2021: the impact of the COVID-19 pandemic on transportation. Available at https://www.retail.ru/articles/logisticheskie-trendy- 2020-2021-goda-vliyaniepandemii-covid-19-na-perevozki (accessed 23.12.2020)

4. Bocharova N.A. The main indicators for assessing the effectiveness of supply chains. Economics of the transport complex. 2019. issue. 34. P.128-142.

5. Dubovik S.G., Sigida N.O., Management of supply chains of enterprises, their essence and structure. Economy and society. 2018. №18. P.402 - 410. 
6. Hanstedt, J. (2020). 5 Best Practices for Implementing Lean Manufacturing. Available at https://www.mcl.bz/blog/5-best-practices-for-implementing-lean-manufacturing (accessed 23.12.2020)

7. Lysons K., Gillingham M. Procurement and Supply Chain Management: INFRA-M, 2012. P.798

8. Gutthorns J., Ogulin R., Reynolds M. Supply Chain Management: Gower Publishing Handbook / ed. INFRA-M, 2010. P.670

9. Demakhin D. M. (2020). Lean second generation. How he transform, and how will transform after quarantine. Available at http://www.uppro.ru/library/production_management/lean/lean-vtorogo-pokoleniya.html (accessed 30.12.2020)

10. Michael Ballé. (2020). Why bother with lean when we're all doomed? Available at https://planet-lean.com/lean-thinking-crisis/ (accessed 30.12.2020)

11. Lean institute of Ukraine. (2020). Available at https://lean.org.ua/pro-lean (accessed 30.12.2020)

12. Lean Global Network. (2020). Available at https://leanglobal.org/lean-globalnetwork/ (accessed 30.12.2020)

13. Raymond Allan G Vergara. Process and Facility Design and Improvement: A Case Study on the Lean Production Management of the Spanish Fashion Retailer Zara. Available at https://www.academia.edu/21680378/Process_and_Facility_Design_and_Improvement_A_Case _Study_on_the_Lean_Production_Management_of_the_Spanish_Fashion_Retailer_Zara (accessed 23.12.2020)

14. Shah R. Defining and developing measures of lean production / R. Shah, P.T. Ward // Journal of Operations Management. - 2007. - No 25. - P. 785 - 805.

15. Official website of LLC "Holod-Engineering" - supplier of industrial, agricultural and technological equipment to the market of Ukraine. (2020). Available at https://h-e.com.ua/uk/ (accessed 23.12.2020)

16. How to Improve On Time In Full Delivery (OTIF) Performance? (2020). Available at https://www.incloudsolutions.co.uk/how-to-improve-on-time-in-full-delivery-otif-performance/ (accessed 23.12.2020)

17. Khrimli T.K., Bozhenko A.A. (2015). Improving the management of current assets of the enterprise based on the use of economic and mathematical models. Available at http://dspace.nbuv.gov.ua. (accessed 23.12.2020)

18. Kuei C. Supply chain quality management: A simulation study. Information and Management Science, 2008. Vol.19, P.131-151.

19. Gross, J., \& McInnis, K. (2003). Kanban made simple. New York: AMACOM.

20. Wheeler D., Chambers D. Statistical process control. Business optimization using Schuhart control cards. M .: Alpina Business Books, 2009. P.272. 